\title{
Interleukin 10 and transforming growth factor beta 1 gene polymorphisms in juvenile idiopathic arthritis
}

\author{
Harsini $\mathrm{S}^{1}$, Ziaee $\mathrm{V}^{2,3}$, Maddah $\mathrm{M}^{3}$, Rezaei A ${ }^{1}$, Sadr $\mathrm{M}^{4}$, Zoghi $\mathrm{S}^{5}$, Moradinejad $\mathrm{MH}^{3}$, Tahghighi $\mathrm{F}^{3,6}$, \\ Aghighi $\mathrm{Y}^{6}$, Rezaei $\mathrm{N}^{1,3,4,5,7}$
}

Research Center for Immunodeficiencies, Children's Medical Center, Tehran University of Medical Sciences, Tehran, Iran.rezaei_nima@tums.ac.ir

\begin{abstract}
OBJECTIVES: The aim of this study is to identify the associations between interleukin 10 (IL-10) and transforming growth factor beta 1 (TGF- $\beta 1$ ) gene polymorphisms and individual susceptibility to juvenile idiopathic arthritis (JIA) in a group of Iranian patients.

BACKGROUND: Cytokine genes, including IL-10 and TGF- $\beta 1$, are known to play important roles in the pathogenesis of JIA.

METHODS: Using polymerase chain reaction with sequence-specific primers method, the frequency of alleles, genotypes and haplotypes of IL-10 (positions -1082, -819, -592) and TGF- $\beta 1$ (codon 10, codon 25) single-nucleotide polymorphisms (SNPs) were investigated in 55 patients with $\mathrm{JIA}$ as a case group and compared with 140 healthy unrelated controls.

RESULTS: The G allele was significantly less frequent at TGF- $\beta 1$ codon 25 in patients with JIA than in the controls $(p<0.01)$. The frequency of CT genotype at TGF- $\beta 1$ codon 10 was found to be higher in healthy individuals in comparison with that in patients group $(p=0.04)$. We observed no differences in the frequency of alleles, genotypes and haplotypes of IL-10 gene between the groups of patients and controls.

CONCLUSIONS: Considering the low frequency of existence of TGF- $\beta 1 \mathrm{G}$ allele at codon 25 as well as TGF- $\beta 1$ CT genotype at codon 10 in patients with JIA, it seems that these cytokine gene polymorphisms could play role as the protective factors against JIA (Tab. 2, Ref. 42). Text in PDF www.elis.sk

KEY WORDS: interleukin 10, transforming growth factor beta 1, single-nucleotide polymorphism, juvenile idiopathic arthritis, children.
\end{abstract}

\section{Introduction}

Juvenile idiopathic arthritis (JIA) belongs to a group of disorders known as chronic inflammatory arthopathies. It is the most common rheumatic disorder with an incidence of $1 / 10,000$ children under the age of 16 years (1). It is widely accepted that JIA is a heterogeneous group of complex diseases with both environmental and genetic factors contributing to its initiation and progression

${ }^{1}$ Research Center for Immunodeficiencies, Children's Medical Center, Tehran University of Medical Sciences, Tehran, Iran, ${ }^{2}$ Pediatric Rheumatology Research Group, Rheumatology Research Center, Tehran University of Medical Sciences, Tehran, Iran, ${ }^{3}$ Pediatrics Center of Excellence, Children's Medical Center, Tehran University of Medical Sciences, Tehran, Iran, ${ }^{4}$ Molecular Immunology Research Center, School of Medicine, Tehran University of Medical Sciences, Tehran, Iran, ${ }^{5}$ Department of Immunology, School of Medicine, Tehran University of Medical Sciences, Tehran, Iran, ${ }^{6}$ Department of Pediatrics, Imam Khomeini Hospital, Tehran University of Medical Sciences, Tehran, Iran, and ${ }^{7}$ Network of Immunity in Infection, Universal Scientific Education and Research Network (USERN), Tehran, Iran Address for correspondence: N. Rezaei, MD, PhD, Research Center for Immunodeficiencies, Children's Medical Center Hospital, Dr Qarib St, Keshavarz Blvd, Tehran 14194, Iran.

Phone: +9821.66929234, Fax: +9821.66929235

Acknowledgements: This study was supported by a grant from Tehran University of Medical Sciences and Health Services (92-03-30-24902).
(2). Although the major histocompatibility locus is a well-known genetic factor involved in the etiopathogenesis of JIA, it does not account for the overall genetic contribution to this disease (3). To date, immunogenetic analyses in JIA have focused on the aforementioned gene, while fewer studies have assessed non-HLA gene variants such as cytokines gene polymorphisms, that have been related to the susceptibility to JIA $(4,5)$.

Interleukin 10 (IL-10), a potent immunoregulatory cytokine, is mainly released by T helper 2 (Th2) cells, macrophages and B cells, and acts as a suppressor of the production of a number of proinflammatory cytokines such as interleukin 6 (IL-6), interleukin 1 (IL-1) and tumor necrosis factor $\alpha(\mathrm{TNF}-\alpha)(6,7)$. IL-10 has been recommended as a stimulatory factor for B lymphocytes, thymocytes as well as mast cells. Decreased IL-10 secretion has been documented in autoimmune disorders, including collageninduced arthritis, psoriasis and rheumatoid arthritis (RA) $(8,9)$.

Transforming growth factor beta 1 (TGF- $\beta 1$ ) is a regulator of the immune response in JIA. This cytokine exerts both anti-inflammatory and pro-inflammatory effects, depending on several, mostly unveiled, factors. TGF- $\beta 1$ induces the differentiation of leukocytes, notwithstanding the fact that it inhibits the multiplication of $\mathrm{T}$ cells and the activation of monocytes and macrophages $(10,11)$.

Contribution of certain cytokines single-nucleotide polymorphisms (SNPs) to a number of immunological diseases has been 
documented (12-18), while our comprehension of JIA is limited due to the paucity of investigations in this area. To the best of our knowledge, this is the first study evaluating possible associations of SNPs in anti-inflammatory cytokines genes with JIA susceptibility in Iranian population.

In the present study, the associations between SNPs in IL-10 at positions $-1082,-819$ and -592 together with TGF- $\beta 1$ at codon 10 and codon 25 and JIA were evaluated in Iranian patients.

\section{Patients and methods}

\section{Subjects}

We recruited fifty-five patients with the clinical diagnosis of JIA from the Rheumatology Clinic of the Children's Medical Center Hospital, the Pediatrics Center of Excellence in Iran and 140 healthy controls who were randomly selected from blood donors at Iranian blood transfusion organizations in the study (19). All patients met the International League Against Rheumatism (ILAR) criteria for JIA (20).

All the entrants to the study gave written informed consent and the study was approved by the Ethical Committee of Tehran University of Medical Sciences.

\section{Genotyping}

Genomic DNA was isolated from whole blood treated with EDTA by a standard "salting out" technique (21). The final preparation was kept at -20 degrees Celsius until investigation. The IL-10 (A/G at $-1098, \mathrm{C} / \mathrm{T}$ at -819 and $\mathrm{A} / \mathrm{C}$ at -592$)$ as well as TGF- $\beta 1$ (C/T at codon 10 and $\mathrm{C} / \mathrm{G}$ at codon 25 ) were determined by polymerase chain reaction with sequence-specific primers (PCR-SSP assay kit, Heidelberg University) (19). Amplification of the extracted gene was performed by a Techne Flexigene thermal cycler (Roche). The following cycling conditions were used: initial denaturation at $94{ }^{\circ} \mathrm{C}$ for 2 minutes; denaturation at $94{ }^{\circ} \mathrm{C}$ for 10 seconds; annealing + extension at $65^{\circ} \mathrm{C}$ for 1 minute $(10$ cycles $)$; denaturation at $94{ }^{\circ} \mathrm{C}$ for 10 seconds; annealing at $61{ }^{\circ} \mathrm{C}$ for 50 seconds; and extension at $72{ }^{\circ} \mathrm{C}$ for 30 seconds ( 20 cycles $)$. PCR products were visualized on a $2 \%$ agarose gel electrophoresis. Thereafter, ultraviolet (UV) transillumination was carried out so as to take a picture for analysis and documentation.

\section{Statistical analysis}

The allele, genotype and haplotype frequencies were estimated by direct gene counting and compared by the chi square test. The odds ratio (OR) and $95 \%$ confidence interval (CI) were calculated for each allele, genotype, and haplotype. Chi square test was used for the evaluation of the Hardy-Weinberg equilibrium. The probability value of less than 0.05 was considered significant.

\section{Results}

Allelic and genotype frequencies in Iranian patients with JIA and healthy control subjects are depicted in Table 1.

The frequency of $\mathrm{C}$ allele of TGF- $\beta 1$ codon 25 was significantly higher in the patients category in comparison with that in healthy controls $(95.5 \%$ vs $7.6 \%, \mathrm{p}<0.01)$. At the genotype level, we observed a lower distribution of heterozygous CT of TGF- $\beta 1$ codon 10 in patients compared to that in controls $(49.1 \%$

Tab. 1. TGF- $\beta 1$ and IL-10 allele and genotype polymorphisms in Iranian patients with juvenile idiopathic arthritis and controls.

\begin{tabular}{|c|c|c|c|c|c|c|}
\hline Cytokine & Position & Alleles/Genotypes & $\begin{array}{c}\text { Controls }(n=140) \\
n(\%)\end{array}$ & $\begin{array}{c}\text { Patients }(n=55) \\
\text { N }(\%)\end{array}$ & $\begin{array}{l}\text { Odds Ratio } \\
(95 \% \mathrm{CI})\end{array}$ & $\mathrm{p}$ value \\
\hline \multirow[t]{5}{*}{ TGF- $\beta 1$} & Codon 10 & $\mathrm{C}$ & $131(47.5)$ & $55(50)$ & $1.11(0.69-1.76)$ & 0.73 \\
\hline & & $\mathrm{T}$ & $145(52.5)$ & $55(50)$ & $0.90(0.57-1.44)$ & 0.73 \\
\hline & & $\mathrm{CC}$ & $20(14.5)$ & $14(25.5)$ & $2.01(0.87-4.65)$ & 0.11 \\
\hline & & CT & $91(65.9)$ & $27(49.1)$ & $0.50(0.25-0.99)$ & 0.04 \\
\hline & & $\mathrm{TT}$ & $27(19.6)$ & $14(25.4)$ & $1.40(0.63-3.12)$ & 0.48 \\
\hline \multirow[t]{7}{*}{ TGF- $\beta 1$} & Codon 25 & $\mathbf{C}$ & $21(7.6)$ & $105(95.5)$ & $255.00(87.48-802.27)$ & $<0.01$ \\
\hline & & G & $255(92.4)$ & $5(4.5)$ & $0.00(0.00-0.01)$ & $<0.01$ \\
\hline & & $\mathrm{CC}$ & $2(1.5)$ & $0(0)$ & $0.00(0.00-10.37)$ & 1.00 \\
\hline & & $\mathrm{GC}$ & $17(12.3)$ & $5(9.1)$ & $0.71(0.22-2.20)$ & 0.70 \\
\hline & & GG & $119(86.2)$ & $50(90.9)$ & $1.60(0.52-5.19)$ & 0.52 \\
\hline & & A & $181(64.6)$ & $66(68.8)$ & $1.20(0.71-2.04)$ & 0.54 \\
\hline & & G & $99(35.4)$ & $30(31.2)$ & $0.83(0.49-1.40)$ & 0.54 \\
\hline \multirow[t]{5}{*}{$\overline{\mathrm{IL}}-10$} & -1082 & AA & $53(37.8)$ & $20(41.7)$ & $1.17(0.57-2.41)$ & 0.77 \\
\hline & & GA & $75(53.6)$ & $26(54.2)$ & $1.02(0.50-2.08)$ & 0.92 \\
\hline & & GG & $12(8.6)$ & $2(4.2)$ & $0.46(0.07-2.31)$ & 0.52 \\
\hline & & $\mathrm{C}$ & $199(71.1)$ & $62(63.3)$ & $0.70(0.42-1.17)$ & 0.19 \\
\hline & & $\mathrm{T}$ & $81(28.9)$ & $36(36.7)$ & $1.43(0.85-2.38)$ & 0.19 \\
\hline \multirow[t]{5}{*}{ IL-10 } & -819 & $\mathrm{CC}$ & $71(50.7)$ & $20(40.8)$ & $0.67(0.33-1.36)$ & 0.30 \\
\hline & & $\mathrm{CT}$ & $57(40.7)$ & $22(44.9)$ & $1.19(0.58-2.41)$ & 0.73 \\
\hline & & $\mathrm{TT}$ & $12(8.6)$ & $7(14.3)$ & $1.78(0.59-5.27)$ & 0.27 \\
\hline & & A & $81(28.9)$ & $36(36.7)$ & $1.43(0.85-2.38)$ & 0.19 \\
\hline & & $\mathrm{C}$ & $199(71.1)$ & $62(63.3)$ & $0.70(0.42-1.17)$ & 0.19 \\
\hline \multirow[t]{3}{*}{ IL-10 } & -592 & $\mathrm{AA}$ & $12(8.6)$ & $7(14.3)$ & $1.78(0.59-5.27)$ & 0.27 \\
\hline & & $\mathrm{CA}$ & $57(40.7)$ & $22(44.9)$ & $1.19(0.58-2.41)$ & 0.73 \\
\hline & & $\mathrm{CC}$ & $71(50.7)$ & $20(40.8)$ & $0.67(0.33-1.36)$ & 0.30 \\
\hline
\end{tabular}


Tab. 2. TGF- $\beta 1$ and IL-10 haplotype polymorphisms in Iranian patients with juvenile idiopathic arthritis and controls.

\begin{tabular}{|c|c|c|c|c|c|c|}
\hline Cytokine & Position & Haplotype & $\begin{array}{c}\text { Controls }(n=140) \\
n(\%)\end{array}$ & $\begin{array}{c}\text { Patients }(\mathrm{n}=55) \\
\mathrm{n}(\%)\end{array}$ & Odds Ratio $(95 \% \mathrm{CI})$ & $\mathrm{p}$ value \\
\hline \multirow[t]{4}{*}{ TGF- $\beta 1$} & Codon 10, Codon 25 & $\mathrm{CG}$ & $110(39.9)$ & $51(46.4)$ & $1.30(0.82-2.09)$ & 0.29 \\
\hline & & TG & $145(52.5)$ & $54(49.1)$ & $0.87(0.55-1.39)$ & 0.62 \\
\hline & & $\mathrm{CC}$ & $21(7.6)$ & $4(3.6)$ & $0.46(0.13-1.46)$ & 0.23 \\
\hline & & $\mathrm{TC}$ & $0(0)$ & $1(0.9)$ & - & 0.17 \\
\hline \multirow[t]{3}{*}{ IL-10 } & $-1082,-819,-592$ & GCC & $99(35.4)$ & $30(31.3)$ & $0.83(0.49-1.40)$ & 0.54 \\
\hline & & $\mathrm{ACC}$ & $100(35.7)$ & $32(33.3)$ & $0.90(0.54-1.51)$ & 0.76 \\
\hline & & ATA & $81(28.9)$ & $34(35.4)$ & $1.35(0.80-2.27)$ & 0.29 \\
\hline
\end{tabular}

vs $65.9 \%, \mathrm{p}=0.04)$. The allele and genotype frequencies of IL10 at positions $-1082,-819$ and -592 were similar in two groups of patients and controls.

As depicted in Table 2, no significant difference was detected between the two groups, neither for GCC, ACC and ATA haplotypes at positions $-1082,-819$ and -592 of IL-10 gene nor for $\mathrm{CG}, \mathrm{TG}, \mathrm{CC}$ and TC haplotypes at codon 10 and codon 25 of TGF- $\beta 1$ gene.

\section{Discussion}

Juvenile idiopathic arthritis (JIA) is known to be a clinically heterogeneous entity with various underlying genetic predisposing factors involved in the etiopathogenesis of this group of disorders. Among the aforesaid gene variants, the association of JIA with certain SNPs within the promoter and coding regions of a multitude of cytokines genes, including IL-10 and TGF- $\beta 1$, have been examined in different ethnic groups with inconsistent results (2224). Furthermore, promoter and coding regions polymorphisms in IL-10 and TGF- $\beta 1$ genes have been correlated with altered levels of circulating IL-10 and TGF- $\beta 1$. Moreover, the majority of the existing data were obtained from the association studies performed on adult patients with rheumatoid arthritis. Therefore there is a paucity of data with regard to the association of the aforementioned cytokine gene SNPs with JIA. This study aims at analyzing the association of IL-10 -1082 G/A, -819 C/T, -592 $\mathrm{C} / \mathrm{A}$ ) and TGF- $\beta 1$ (codon $10 \mathrm{C} / \mathrm{T}$, codon $25 \mathrm{C} / \mathrm{G}$ ) polymorphisms in Iranian patients with JIA.

TGF- $\beta 1$, a member of a family of growth factors, which has been detected in the synovial tissue of RA patients, exerts modulatory effects on lymphocytes, macrophages, dendritic cells, chondrocytes, fibroblasts and osteoblasts. This cytokine has been detected in both inactive and the active forms in rheumatoid joints (25). The gene encoding TGF- $\beta 1$ is situated at chromosome 19q13, which comprises seven exons (26). Two cytokine SNPs located on codon 10 (T869C, Leu/Pro) and codon 25 (G915C, Arg/Pro) in the coding sequence of TGF- $\beta 1$ gene, both of which have been reported to be correlated with the variations in the levels of TGF- $\beta 1$, were examined in this study (27). In the present study, TGF- $\beta 1$ CT genotype at codon 10 was significantly higher in healthy controls compared with that in JIA patients. On the contrary, Cinek et al did not recognize any association between TGF- $\beta 1$ SNPs and JIA proneness in Czech population (28). Two meta-analysis studies carried out by Chang et al (29) and Zhang et al (30) divulged an association between TGF- $\beta 1$ T869C polymorphism and RA in the people of Asian descent, but not in the people of non-Asian descent. On the other hand, our findings are not in line with the investigation performed by Hussein et al, who found the TGF- $\beta 1 \mathrm{~T}$ allele at codon 10 to be associated with susceptibility to RA (25). In addition, our findings revealed the decreased frequency of $\mathrm{G}$ allele of TGF- $\beta 1$ at codon 25. On the other hand, Muñoz-Valle et al found no associations between TGF- $\beta 1$ G915C polymorphism with RA (31).

IL-10, known as an immunoregulatory cytokine, exerts its antiinflammatory effect by impeding the production of proinflammatory cytokines, including TNF- $\alpha$, IL- $1 \beta$, and IL- 8 by human polymorphonuclear leukocytes (32), IFN- $\gamma$ synthesis in T cells (33), and IL- $1 \alpha$, IL-1 $\beta$, IL-6, IL-8, IL-12, and TNF- $\alpha$ release from activated macrophages (34). Additionally, IL-10 appears to be effective in blocking mononuclear cell traffic into synovial tissue by downregulating intercellular adhesion molecule 1 expression by synovial cells $(35,36)$, mitigating inflammation in the collagen-induced arthritis animal model (37), inhibiting the action of proinflammatory cytokines IL- $1 \alpha$ and IL- $1 \beta$ by enhancing the release of soluble IL-1 receptor antagonist (34), reversing cartilage degradation by mononuclear cells from RA patients in tissue culture (38), and ameliorating proinflammatory cytokine synthesis by mononuclear cells from peripheral blood, synovial cells and synovial fluid of patients with RA (38). Previous studies on patients with JIA have indicated the reduced production of IL-10 from whole blood culture (39). The gene encoding for IL10 is situated within a highly conserved cytokine gene cluster on chromosome 1q32 (40). In the current study, we have examined 3 functional SNPs at -1082A/G (rs1800896), -819C/T (rs3021097), and $-592 \mathrm{~A} / \mathrm{C}$ (rs1800872) of IL-10. Associations between these IL-10 gene variants and RA have been reported $(23,41)$. We observed no associations between the above-mentioned IL-10 gene polymorphisms with individual's susceptibility to JIA in Iranian population. Similarly, Cinek et al found no significant association between IL-10 gene variants and JIA vulnerability in Czech population (28). Contrarily, Möller et al demonstrated a significantly increased frequency of low IL-10 expressing -1082A/A alleles, medium IL-10 expressing ACC haplotype, and GTC haplotype, as well as the decreased frequency of heterozygous $-1082 \mathrm{G} / \mathrm{A}$ alleles, and the GCC haplotype in patients with systemic juvenile idiopathic arthritis (sJIA) in a German population (42). Fife et al also revealed a significant increased 
prevalence of the low expressing IL-10 -1082 genotype in British patients with sJIA (3).

In conclusion, our results suggest that the TGF- $\beta 1 \mathrm{G}$ allele at codon 25 as well as TGF- $\beta 1$ CT genotype at codon 10 confers protection against JIA in Iranian population. Nevertheless, our findings should be interpreted with caution due to the small number of the patients enrolled in the study. The other limitation of our investigation that needs to be acknowledged is our constraint to measure the levels of IL- 10 and TGF- $\beta 1$ production and thus, our inability to analyze the influence of cytokine gene SNPs on their level of synthesis. As a result, recruitment of larger sample size in populations of different ethnicities are required to verify the roles of these polymorphisms of the IL- 10 and TGF- $\beta 1$ genes in the pathogenesis of RA.

\section{References}

1. Symmons DP, Jones M, Osborne J, Sills J, Southwood TR, Woo P. Pediatric rheumatology in the United Kingdom: data from the British Pediatric Rheumatology Group National Diagnostic Register. J Rheumatol 1996; 23 (11): 1975-1980.

2. Petty RE, Southwood TR, Baum $\mathbf{J}$ et al. Revision of the proposed classification criteria for juvenile idiopathic arthritis: Durban, 1997. J Rheumatol 1998; 25 (10): 1991-1994.

3. Fife MS, Gutierrez A, Ogilvie EM et al. Novel IL10 gene family associations with systemic juvenile idiopathic arthritis. Arthritis Res Ther 2006; 8 (5): R148.

4. Fishman D, Faulds G, Jeffery R et al. The effect of novel polymorphisms in the interleukin-6 (IL-6) gene on IL-6 transcription and plasma IL-6 levels, and an association with systemic-onset juvenile chronic arthritis. J Clin Invest 1998; 102 (7): 1369-1376.

5. Oen K, Malleson PN, Cabral DA et al. Cytokine genotypes correlate with pain and radiologically defined joint damage in patients with juvenile rheumatoid arthritis. Rheumatology (Oxford) 2005; 44 (9): 1115-1121.

6. Amanvermez R, Gunay M, Piskin A, Keles G, Tomak L. TNF- $\alpha$, IL$1 \beta$, and oxidative stress during fracture healing with or without ankaferd. Bratislavske lekarske listy 2012; 114 (11): 621-624.

7. de Waal Malefyt R, Abrams J, Bennett B, Figdor CG, de Vries JE. Interleukin 10(IL-10) inhibits cytokine synthesis by human monocytes: an autoregulatory role of IL-10 produced by monocytes. J Exp Med 1991; 174 (5): 1209-1220.

8. Moore KW, de Waal Malefyt R, Coffman RL, O'Garra A. Interleukin-10 and the interleukin-10 receptor. Annu Rev Immunol 2001; 19 683-765.

9. Noble KE, Harkness D, Yong KL. Interleukin 10 regulates cellular responses in monocyte/endothelial cell co-cultures. Br J Haematol 2000; 108 (3): 497-504.

10. Ceccarelli F, Perricone C, Fabris $M$ et al. Transforming growth factor beta $869 \mathrm{C} / \mathrm{T}$ and interleukin $6-174 \mathrm{G} / \mathrm{C}$ polymorphisms relate to the severity and progression of bone-erosive damage detected by ultrasound in rheumatoid arthritis. Arthritis Res Ther 2011; 13 (4): R111.

11. Feltl D, Zavadova E, Pala M, Hozak P. Posttreatment plasma transforming growth factor beta 1 (TGF-beta1) level predicts for late morbidity in patients with advanced head and neck cancer. Neoplasma 2005; 52 (5): 393.
12. Amirzargar A, Bagheri M, Ghavamzadeh A et al. Cytokine gene polymorphism in Iranian patients with chronic myelogenous leukaemia. International journal of immunogenetics 2005; 32 (3): 167-171.

13. Amirzargar A, Shahram F, Nikoopour E et al. Proinflammatory cytokine gene polymorphisms in Behcet's disease. Eur Cytokine Netw 2010; 21 (4): 292-296.

14. Amirzargar AA, Rezaei N, Jabbari $H$ et al. Cytokine single nucleotide polymorphisms in Iranian patients with pulmonary tuberculosis. Eur Cytokine Netw 2006; 17 (2): 84-89.

15. Mahdaviani SA, Rezaei N, Moradi B, Dorkhosh S, Amirzargar AA, Movahedi M. Proinflammatory cytokine gene polymorphisms among Iranian patients with asthma. J Clin Immunol 2009; 29 (1): 57-62.

16. Mahmoudi $M$, Tahghighi $F$, Ziaee $\mathbf{V}$ et al. Interleukin- 4 single nucleotide polymorphisms in juvenile systemic lupus erythematosus. Int $\mathrm{J}$ Immunogenet 2014;

17. Rezaei N, Amirzargar AA, Shakiba Y, Mahmoudi M, Moradi B, Aghamohammadi A. Proinflammatory cytokine gene single nucleotide polymorphisms in common variable immunodeficiency. Clin Exp Immunol 2009; 155 (1): 21-27.

18. Ziaee V, Tahghighi F, Moradinejad MH et al. Interleukin-6, interleukin-1 gene cluster and interleukin-1 receptor polymorphisms in Iranian patients with juvenile systemic lupus erythematosus. Eur Cytokine Netw 2014; 25 (2): 35-40.

19. Amirzargar AA, Naroueynejad M, Khosravi F et al. Cytokine single nucleotide polymorphisms in Iranian populations. Eur Cytokine Netw 2008; 19 (2): 104-112.

20. Petty RE, Southwood TR, Manners P et al. International League of Associations for Rheumatology classification of juvenile idiopathic arthritis: second revision, Edmonton, 2001. J Rheumatol 2004; 31 (2): 390-392.

21. Miller S, Dykes D, Polesky H. A simple salting out procedure for extracting DNA from human nucleated cells. Nucleic acids research 1988; 16 (3): 1215.

22. Ates O, Hatemi G, Hamuryudan V, Topal-Sarikaya A. Tumor necrosis factor-alpha and interleukin-10 gene promoter polymorphisms in Turkish rheumatoid arthritis patients. Clin Rheumatol 2008; 27 (10): 1243-1248.

23. Lee YH, Bae SC, Choi SJ, Ji JD, Song GG. Associations between interleukin-10 polymorphisms and susceptibility to rheumatoid arthritis: a meta-analysis. Mol Biol Rep 2012; 39 (1): 81-87.

24. Pokorny V, Chau J, Wu L et al. Transforming growth factor beta 1 gene (HSTGFB1) nucleotide T869C (codon 10) polymorphism is not associated with prevalence or severity of rheumatoid arthritis in a Caucasian population. Ann Rheum Dis 2003; 62 (9): 907-908.

25. Hussein YM, Mohamed RH, El-Shahawy EE, Alzahrani SS. Interaction between TGF-beta1 (869C/T) polymorphism and biochemical risk factor for prediction of disease progression in rheumatoid arthritis. Gene 2014; 536 (2): 393-397.

26. Clark DA and Coker R. Transforming growth factor-beta (TGF-beta). Int J Biochem Cell Biol 1998; 30 (3): 293-298.

27. Alayli G, Kara N, Tander B, Canturk F, Gunes S, Bagci H. Association of transforming growth factor beta 1 gene polymorphism with rheumatoid arthritis in a Turkish population. Joint Bone Spine 2009; 76 (1): 20-23.

28. Cinek O, Vavrincova P, Striz I et al. Association of single nucleotide polymorphisms within cytokine genes with juvenile idiopathic arthritis in the Czech population. J Rheumatol 2004; 31 (6): 1206-1210. 


\section{8-262}

29. Chang WW, Su H, He L, Zhao KF, Wu JL, Xu ZW. Association between transforming growth factor-beta1 T869C polymorphism and rheumatoid arthritis: a meta-analysis. Rheumatology (Oxford) 2010; 49 (4): $652-656$.

30. Zhang L, Yan JW, Wang YX et al. Association of TGF-beta $1+869 \mathrm{C} / \mathrm{T}$ promoter polymorphism with susceptibility to autoimmune diseases: a meta-analysis. Mol Biol Rep 2013; 40 (8): 4811-4817.

31. Munoz-Valle JF, Torres-Carrillo NM, Guzman-Guzman IP et al. The functional class evaluated in rheumatoid arthritis is associated with soluble TGF-beta1 serum levels but not with G915C (Arg25Pro) TGFbeta1 polymorphism. Rheumatol Int 2012; 32 (2): 367-372.

32. Cassatella MA, Meda L, Bonora S, Ceska M, Constantin G. Interleukin 10 (IL-10) inhibits the release of proinflammatory cytokines from human polymorphonuclear leukocytes. Evidence for an autocrine role of tumor necrosis factor and IL-1 beta in mediating the production of IL-8 triggered by lipopolysaccharide. J Exp Med 1993; 178 (6): 2207-2211.

33. Macatonia SE, Doherty TM, Knight SC, O'Garra A. Differential effect of IL-10 on dendritic cell-induced T cell proliferation and IFN-gamma production. J Immunol 1993; 150 (9): 3755-3765.

34. Crawley E, Kay R, Sillibourne J, Patel P, Hutchinson I, Woo P. Polymorphic haplotypes of the interleukin-10 5' flanking region determine variable interleukin-10 transcription and are associated with particular phenotypes of juvenile rheumatoid arthritis. Arthritis Rheum 1999; 42 (6): 1101-1108.

35. Jorgensen C, Apparailly F, Couret I, Canovas F, Jacquet C, Sany J. Interleukin-4 and interleukin-10 are chondroprotective and decrease mononuclear cell recruitment in human rheumatoid synovium in vivo. Immunology 1998; 93 (4): 518-523.

36. Kawakami A, Eguchi K, Matsuoka $\mathbf{N}$ et al. Inhibitory effects of interleukin-10 on synovial cells of rheumatoid arthritis. Immunology 1997; 91 (2): 252-259.

37. Joosten LA, Lubberts E, Durez P et al. Role of interleukin-4 and interleukin-10 in murine collagen-induced arthritis. Protective effect of interleukin-4 and interleukin-10 treatment on cartilage destruction. Arthritis Rheum 1997; 40 (2): 249-260.

38. van Roon JA, van Roy JL, Gmelig-Meyling FH, Lafeber FP, Bijlsma JW. Prevention and reversal of cartilage degradation in rheumatoid arthritis by interleukin-10 and interleukin-4. Arthritis Rheum 1996; 39 (5): 829-835.

39. Muller K, Herner EB, Stagg A, Bendtzen K, Woo P. Inflammatory cytokines and cytokine antagonists in whole blood cultures of patients with systemic juvenile chronic arthritis. Br J Rheumatol 1998; 37 (5): 562-569.

40. Omoyinmi E, Forabosco P, Hamaoui R et al. Association of the IL10 gene family locus on chromosome 1 with juvenile idiopathic arthritis (JIA). PLoS One 2012; 7 (10): e47673.

41. Zhang J, Zhang Y, Jin J et al. The $-1082 \mathrm{~A} / \mathrm{G}$ polymorphism in the Interleukin-10 gene and the risk of rheumatoid arthritis: a meta-analysis. Cytokine 2011; 56 (2): 351-355.

42. Moller JC, Paul D, Ganser G et al. IL10 promoter polymorphisms are associated with systemic onset juvenile idiopathic arthritis (SoJIA). Clin Exp Rheumatol 2010; 28 (6): 912-918. 